\title{
Notes on the Echinoderms collected by Mr. Bourne in Deep Water off the South-west of Ireland in H.M.S. "Research."
}

By

\section{F. Jefrey Bell, M.A., Sec. R.M.S.}

Mr. Bourne has been good enough to submit to me most of the interesting specimens of Echinoderms which he obtained during his short stay on board H.M.S. "Research." Coming so soon after the important collection made by the Rev. W. S. Green in neighbouring. waters and at greater depths, it will, I think, suffice for me to treat this collection as an appendix to that, and to refer for a general discussion of such points as appeared worth noting to my report in the Annals and Magazine of Natural History for December last.

The great interest of Mr. Bourne's collection lies in the remarkable way in which the depths of some of our more common shallowwater species is increased, in some cases indeed to a remarkable extent; see the cases of Stichaster roseus, Asterias rubens, A. glacialis, and Spatangus purpureus.

The species which were observed on board ship, but which were not preserved, are indicated by an asterisk.

A list of Mr. Bourne's stations is given on p. 306 .

\section{Asteroidea.}

Pontaster tenuispinis, $D$. and $K$.

Taken at several stations from 90 to 400 fath.

*Psilaster andromeda, $M$. Tr.

Station 2.

*Luidia ciliaris, Phil.

Stations 5 and 7. 
Porania pulvillus, $O$. F. $M$.

\section{Station 7.}

* Palmipes placenta, Penn.

Stations 7 and 8 . The range given by Mr. Sladen for this species is 2-100 fath. ; but, as he also remarks that the "Porcupine" specimens are without exact locality or conditions, it is well to have a definite statement for British specimens.

Stichaster roseus, $O . F . M$.

Station 1. The depth-200 fath.-is an advance by 150 on any yet recorded.

*Astertas rubens, Linn.

Stations 1,5, and 8. Mr. Bourne calls my attention to the depth of 200 fath.; Mr. Green did the same for his depth of 100 fath. This considerable increase in the range of these two species is significant.

*Asterias glacialis, $O . F . M$.

Station 5. The range of this species is increased from 66 to 90 fath.

Brisinga Coronata, Sars.

Fragments only.

\section{OpHiURoIdea.}

Ophiocten sericeum, Forbes.

Station 2.

Ophiopholis aculeata, Limn.

Station 7. Young specimens.

Ophiothrix pentaphyllum, Penn.

Stations 1 and 5. Mr. Bourne, I notice, has labelled these specimens 0 . Luetkeni. Before long I hope to be able to marshal the evidence regarding the variability of 0 . pentaphyllum which is in my possession in such a way as to justify the doubts which Sir Wyville Thomson always had as to the distinctness of $O$. Luetkeni. 
Ophiobyrsa hystricis, Lym.

It seems very probable that the remarkable Ophiurid to which I refer in the introduction to my report on Mr. Green's collection belongs to this species, but a close and extended investigation is required. Mr. Bourne's specimen is from Station 2.

Cidaris papillata.

ECHinoidea.

Stations 2, 3, and 4 .

Echinus acutus, Lamk.

Station 8 .

*Echinus esculentus, Linn.

Station 6.

Echinus norvegicus, $D$. and $K$.

Station 2. This species was not collected by Mr. Green, and I am very glad to be able to put it with those collected by him.

Spatangus purpureus, $O$. F. $M$.

Stations 1, 2, 4, 5, 8; very abundant 1, 2, 4. I should, after what I have been able to see of the variations of this species and of $S$. raschi, been particularly pleased had all the Spatangi from more than 100 fath. been preserved. In suggesting the possibility of intercrossing between the two species I felt I was going beyond my record for the time, inasmuch as I had not then evidence that S. purpureus lived at depths as great or greater than 100 fath.

\section{HOLOTHURIOIDEA.}

Holothuria tremula, Gunner.

Stations 1, 2, 4, 8.

\section{NOTE.}

Besides the Echinoderms above described I obtained three Asterids which appeared to me to be very similar to Nymphaster protentus, Sladen, described by Sladen in the "Challenger" Report of the Asteroidea. But as I thought that I could distinguish some differences in my specimens, I sent them to Mr. Sladen for examination 
before I had thought of sending the whole collection of Echinoderms to Prof. Bell. Hence they do not appear in the above report.

Mr. Sladen writes to me as follows:- "The two star-fishes you sent are very fine examples of Nymphaster protentus, which I described in the Report ' Challenger' Asteroidea. They are larger than the type. One differs in having occasionally a small pedicellaria on the marginal plates like those on the abactinal plates. Their presence in your specimens is probably due to age. The second specimen differs in having a small spiniform granule, the largest about $1 \mathrm{~mm}$. in length, on the infero-marginal plates on the inner two thirds of the ray, and a similar but smaller granule on a few of the innermost supero-marginal plates, not more than five or six being present in each interbrachial arc. This is to the eye a striking difference, but I do not consider it to be essentially of any great importance. I therefore shrink from ranking the example as a distinct variety of Nymphaster protentus on the basis of a single specimen, for the character in question is one subject to much variation in other forms, and may be sexual." Since I received this letter Canon Norman has called my attention to the fact that Nymphaster protentus, Sladen, is, in its younger condition, indistinguishable from Pentagonaster subspinosus of the "Blake" Expedition described by Perrier in 1884 (Mém. sur les Etoiles de mer recueilles dans la mer des Antilles et le Golfe du Mexique, Nouv. Archiv. du Muséum d'Hist. Nat., ser. 2, tom. vi, p. 234, plate vi, fig. 1). Perrier's specific name must therefore be adopted, and the range of the species is thus considerably extended. By the "Blake" Expedition it was dredged in 163-209 fathoms, off Havana, Barbadoes, and Cariacon; by the "Challenger" at Station 3, south-west of the Canary Islands, lat. $25^{\circ} 45^{\prime}$ N., long. $20^{\circ} 14^{\prime}$ W., 1525 fath.; by the "Flying Fox" off the south-west of Ireland in 315 fath., and by the "Research." For a description of the "Flying Fox" specimens, described as Nymphaster protentus, see Prof. Bell's paper, Ann. Mag. Nat. Hist., ser. 6, vol. iv, p. 434 .

G. C. B. 